\title{
SERIAL VERB CONSTRUCTIONS IN SASAK LANGUAGE OF MENO-MENE DIALECT: A TYPOLOGY AND LFG APPROACH
}

\author{
Sartika Hijriati \\ STMIK MATARAM \\ sartika.hijriati@gmail.com
}

\begin{abstract}
ABSTRAK - Penelitian ini bertujuan menganalisis tipe-tipe semantik, ciri-ciri, dan struktur konstituen dan struktur fungsional pada konstruksi verba serial Bahasa Sasak. Teori yang digunakan untuk menganalisis data adalah teori tipologi dan tata bahasa leksikal fungsional. Penelitian ini dirancang sebagai penelitian deskriptif kualitatif. Pengumpulan data pada penelitian ini menggunakan metode observasi, wawancara dan introspektif-reflektif dengan teknik rekam dan pancing. Hasil analisis menunjukkan konstruksi verba serial bahasa Sasak memiliki sepuluh tipe semantik untuk menunjukkan gerakan, arah, instrumen, komitatif, kecaraan, aspek dan modal, benefaktif, kausatif, sebab-akibat, dan sinonim. Berdasarkan ciriciri fonologis, morfologis dan sintaksis, verba serial Bahasa Sasak memiliki ciri: 1) konstruksi verba serial Bahasa Sasak dilafalkan dalam satu intonasi, 2) konstruksi verba serial Bahasa Sasak ialah monoklausa dan berperilaku sebagai predikat tunggal, 3) pemarkah verba serial Bahasa Sasak pada salah satu atau tiap-tiap verba dengan pemarkah yang sama, 4) verba serial Bahasa Sasak berbagi aspek, modal dan negasi, dan 5) verba serial Bahasa Sasak berbagi argumen dalam konstruksinya. Analisis terhadap struktur konstituen dan struktur fungsional menunjukkan verba serial bahasa Sasak memiliki stuktur V-V dan struktur X-KOMP atau X-ADJ.

Kata Kunci: konstruksi verba serial, tipologi, tata bahasa leksikal fungsional, sasak
\end{abstract}

\section{INTRODUCTION}

Sasak is a Western-Malayo-Polynesian language spoken on Lombok Island, West Nusa Tenggara province in eastern Indonesia. This language has around 2.7 million speakers or $85 \%$ of the population of Lombok. Sasak is closely related to Samawa and Balinese, as a member of Austronesian languages (Austin, 2012: 1).

Austin divided Sasak into five dialects recognized by native speakers and named for the term of shibboleth for meaning 'like that-like this' which are Ngeto-ngene, Nggeto-nggete, Meno-mene, Kuto-kute, Meriak-meriku (2003: 1). Ngenongene dialect is mostly spoken in East Lombok and West Lombok, meno-mene dialect or Pejanggik dialect is spoken in Central Lombok, meriak-meriku dialect is spoken in Central Lombok and some in East Lombok, kuto-kute and nggeto-nggete dialect is spoken in the Northwest of Lombok and some in East Lombok.

The uniqueness of Sasak is that it has a lot of serial verbs. Thus, I am interested in analyzing the characteristics of Sasak serial verb, and what types of verbs filling Sasak serial verbs. Semantically, the verbs need to be proven whether each verb has close relation to the other verb in Sasak serial verb constructions.

Some studies dealing with Sasak language have been conducted, but few of them discussed serial verbs as a predicate in a clause. Therefore, I am interested in exploring the construction of serial verbs in Sasak especially in meno-mene dialect that has not received the attention of other researchers.

The deep analysis on the constructions of serial verbs is not only limited to the syntactical aspects, but also from the aspect of morphology and meaning of verbs that build the constructions as well. I used theory of Typology and Lexical Functional Grammar (LFG) in this research to discuss the aspects of Sasak serial verb constructions.

From the phenomena above, this research aims to explain: 1) the semantic types of serial verb constructions in Sasak 2) the characteristics of serial verb constructions in Sasak 3) the constituent structure (c-str) and functional structure (fstr) of serial verb constructions in Sasak.

Therefore, the results of this research can be used to demonstrate serial verb constructions phenomena found in Sasak. In addition, this research can also be used as a complete description of the theory of Typology and Lexical Functional Grammar (LFG) theory to analyze and explain the semantic types, the characteristics, and the constituent structure (c-str) and functional structure (f-str) of Sasak serial verb constructions. Practically, this research provides literatures which can enrich Sasak syntactical analysis. It can also be a proper source for those who want to study and 
explore their knowledge of the syntax in Sasak especially meno-mene dialect, with different approach. In addition, the result of this research can give a positive response to the Sasak speakers as the maintenance of Sasak language in West Nusa Tenggara.

Numerous studies of Sasak language have already been conducted and presented in various forms such as thesis and journals. There are also some previous studies discussing serial verb constructions. The following description will highlight the differences of this research with the other researches.

Firstly, Sukri (2008) explored the morpho-phonological process in Sasak of Kuto-Kute Dialect using the theory of generative morphology. Secondly, Pradnyayanti (2010) analyzed double verb constructions in Ngeto-Ngete Dialect of Sasak. Her discussion was begins with the description of the basic clause structures of Sasak Ngeto-Ngete which are classified based on the subject and predicate position as well as the category of the words functioned as the predicates. Thirdly, Liswahyuningsih (2011) discussed the phenomena of the use of serial verb constructions in Indonesian and their equivalents in English. The data were taken from Laskar Pelangi and The Rainbow Troops.

Furthermore, Austin (2011) in his paper entitled "Tense, aspect, mood, and evidentiality in Sasak, eastern Indonesia" discussed the forms and functions of preverbal auxiliary particles in Sasak. Austin (2012) also discussed the distribution of nasal-prefix verbs in his paper entitled "Too many nasal verbs: dialect variation in the voice system of Sasak". Moreover, Subiyanto (2013) analyzed complex predicates in Javanese from the syntactic aspect and pragmatic aspect, especially information structure in his dissertation. The last, Budiarta (2013) discussed base structure clause, predication, valency, function and grammatical relation, and complex sentences. The aim of his reserach was to explore the grammatical alliance system to define Kemak syntax typology.

\section{THEORETICAL FRAMEWORK}

Based on the morphological, syntactical, or semantical characteristics, verbs in Sasak of meno-mene dialect are distinguished into main verbs and auxiliary verb. Morphologically, main verbs commonly have verbal affixes, prefix nge-, $m e-$, be- and nasal as marker of active form of transitive verb and prefix te- as marker of passive form.

Durie (1988: 3 ) explained serial is what happens when two or more verbs are juxtaposed in such a way that they act as a single predicate. He also stated the verbs in serialization are bound together syntactically and/or morphologically. They share one or more arguments. Typically in a serial construction there is no subordination or coordination marker, and the verbs cannot have separate scope for tense, mood, aspect, and negation (1988: 3). Serial verb constructions are marked by the existence of two or more verbs in a single clause and not separated by any conjunction.

Aikhenvald (2006: 4-12) explained serial verb construction (SVC) as follow: (1) SVC as a single predicate, (2) SVC is mono-clause and allow no markers of syntactic dependency on its component, (3) SVC has the intonation properties of a mono-verbal clause, (4) SVC shares tense/aspect, mood, modality, and (5) SVC shares arguments.

Serial verb constructions are very often said to express a single event (Aikhenvald 2006:1, van Staden and Reesink 2008: 22) and they "act together as a single predicate" (Aikhenval 2006: 1) or "like a single verb" (Durie 1997: 290). That the serial verb constructions encode a single event is solved by Pawley's statement (1996: 197) typically the different verbs in an SVC are linked, grammatically, to the point where they form a single complex predicate and have the same kinds of argument structures as single verbs do. He stressed that the separate (sub)events denoted by each verb in a SVC must be integrated conceptually into a single complex event.

Apart from those morpho-syntactical characteristics, serial verb constructions can be divided based on the semantic types. Van Staden and Reesink (2008) noted seven types of the semantic types of serial verb construction of languages in East Nusantara, especially the Austronesian and Papuan languages. Those seven semantic types are motion, direction, instrument, comitative, manner, aspect, and mood.

Lexical Functional Grammar (LFG), a non-transformational generative grammar 
theory that was developed by Bresnan and Kaplan in 1970's, but its echo began to appear in 1990's. In LFG, language is described in parallel structures which are related to one another (Dalrymple, 2001). LFG appears because of dissatisfaction on the idea of transformation in which the existence of lexical entries (the knowledge of grammar and vocabulary) will appear naturally in the minds of the speakers both morphologically and syntactically. LFG also appears as an attempt to get an alternative model of grammar for explaining the phenomena of languages all over the world, typologically.

\section{RESEARCH METHOD}

This study is a descriptive qualitative research. It is called descriptive because this research attempts to describe all aspects of serial verb constructions in Sasak. I have noticed that Sasak also shows complex system of speech levels, but this study uses the data from low levels of meno-mene dialect. This language variation is the most commonly used form of meno-mene dialect of Sasak. The data of this research are sentences which were drawn from utterances of Sasak native speakers of meno-mene dialect.

The research location is Praya, one of the cities located in Central Lombok, West Nusa Tenggara Province. This city was chosen because this is the area where the meno-mene dialect is spoken. The utterances used as the data source selected based on some terms and conditions, not arbitrary. Based on several criteria below, I invited five speakers of Sasak as informants. The informants were chosen based on the following criteria:

a. The respondents are native speakers of meno-mene dialect.

b. They are able to speak in menomene dialect well.

c. They are between 25 up to 70 years old.

d. They are graduated at least from elementary school.

e. They are ready to be informants in this research and have available time.

f. They do not go travelling frequently outside the area of Praya.

g. They are healthy and have good articulation, or not defective in speech production.

In collecting the data, I apply observation, interview, and reflective- introspective metods with recording and elicitation techniques. The technique applied in collecting the data was notetaking technique. The elicitation technique was also used to test with the informants the grammatical acceptibility of Sasak serial verb constructions. In this research, I also apply reflective-introspective method (Sudaryanto, 1993: 121). In this case, as a Sasak native speakes of meno-mene dialect, I use my linguistic intuition to create data and test the acceptability of the data. The data that I made were then consulted with the informants to check their grammatical acceptability.

\section{FINDING AND DISCUSSION}

a. The Semantic Types of Sasak Serial Verb Constructions

\section{Motion Serial Verb Constructions}

In many languages, the verb expressing a motion, typically 'go', precedes some action by the same actor (Talmy 2000 in van Staden and Reesink, 2008: 36). In motion serial verb of Sasak, motion verb is found commonly in the first verb such as lampaq 'walk', as seen in:

(1) Amaq lampaq oleq inggas begaleng.

father walk go.home CONJ breakfast

'Father is going home after lunch.'

\section{Directional Serial Verb Constructions}

Directional serial verb constructions have two components of semantic, path or location related to directional meaning and manner related to motion (Talmy in van Staden and Reesink, 2008: 38).

(2) Papuq lalo be-daye. grandfather go go.to.the.north 'Grandfather goes to north.'

Instrumental Serial Verb Constructions Instrumental serial verb in Sasak is formed by verb which expresses instrumental verb after the action verb. The instrumental verb is stating the use of tools or instruments. See example below:

(3) Inaq lalo be-dokar jok peken. mother go use.cidomo Prep market

'Mother is riding a cidomo to the market.'

\section{Comitative Serial Verb Constructions}

Comitative serial verb in Sasak is formed by comitative verb, or verb involved a verb meaning 'accompany/together with', which followed by intransitive or transitive verb. Verbs express comitative have the same 
agent with other verb as intransitive verb and transitive verb which are expressing an action. Sasak has comitative serial verb which is formed by milu 'accompany/together with' followed by the other verb which is expressing an action. See the examples below:
(4) Tiang milu
meken
lemak aru.
1-S be.with N-go.to.the.market tomorrow
'I come along to the market tomorrow morning.'

\section{Manner Serial Verb Constructions}

Manner serial verb can be formed by intransitive verb, transitive verb, and verb that explain how an action is completed. Manner serial verb constructions in Sasak are divided into those that have to follow the intransitive verb, and those have to precede the transitive verb.

(5) Amaq tokol be-sile.

father sit cross-leg

'Father is cross-legged sitting.'

\section{Aspect and Mood Serial Verb} Constructions

Aspect and mood serial verb in Sasak is formed by a main verb and an aspectual or modal auxiliary verb. In Sasak, verbs that indicating aspects are selese 'finish', engkah 'stop', tetep 'still', while verbs that indicating moods are mele 'want' or melet 'want so much/desire'. Those forms of aspectual or modal are different from aspect markers such as uah 'done', eaq 'will', and mood markers such as tao 'can', harus 'must', mesti 'must', and kadi 'must'.

\section{(6) Amaq melet ngupi.}

father MOD N.drink.coffee

'Father wants to drink a cup of coffee.'

\section{Benefactive Serialization}

Benefactive serialization contains two or more verbs, the second of which is always one of two verbs in Sasak beng, meaning 'to give'.

\section{(7) Inaq oleq nyusu.}

mother go.home N.give brother N.do.breastfeed

'Mother returns home for breastfeeding brother.'

\section{Causative Serialization}

The first verb in Sasak causative is always the verb pinaq or piyaq 'do, make' and the second is typically an intransitive verb. This can be seen as seen in clause (19), which contains the intransitive verb menenjot 'shock'
(8) Nie miyaq menenjot bebeaq no.

3-S N.make make.shock baby DEM 'S(he) shocked the baby.'

\section{Cause-Effect Serialization}

Cause-effect serialization in Sasak is formed by independent verbs. Cause-effect serial verb consist of verb which stated effect is the second verb, while the first verb stating the cause. Here are the examples:

(9) Ariq meneq $\boldsymbol{m}$-basaq-an kasur. brother N.pee N.make.wet bed 'Brother has peed the bed.'

\section{Synonym Serialization}

Synonym serialization in Sasak consists of two intransitive verbs which contain the same meaning or almost same meaning. The relation between PRED1 and PRED2 in this type of Sasak serial verb constructions is very stiff and they appear in a row.

(10) Dita mopoq

natap inggas mangan.

name N.wash N.wash CONJ eat

'Dita is doing laundry after breakfast.'

\section{b. The Characteristics of Sasak Serial Verb Constructions}

Sasak serial verb constructions fall under one intonation contour

The phonological characteristic of Sasak serial verb constructions, as explained below, has the similarity with the characteristics of serial verb constructions cross-linguistically. Aikhenvald (2006: 7) stated that serial verb construction has the intonation properties of a mono-verbal clause, which are indicated by an intonation break in many languages. This is found also in Sasak, as seen in the examples:
(11) a. Ariq nangis ngendeng aik susu. brother N.cry ask water milk
'Brother is crying because of thirsty.'

Sasak serial verb constructions form mono-clause as a single predicate

Verbs which form serial verb constructions act together as single predicates in a clause, and often translatable into non- 
serializing language, as we can see in the following example:

(12) Amaq besoq pandiq
montor=n.
father clean take.a.bath
motorcycle=3S
'Father is washing his
motorcycle.'

Sasak serial verb markers occur only on one verb or each verb obtains the same marker

The morphological characteristic of Sasak serial verb constructions explained below has similarity with the characteristics of serial verb constructions crosslinguistically, that according to Aikhenvald (2006: 3-4) some verbal categories may have to be marked on every verb in a series, or just once per constructions, as seen in the following example:

$$
\begin{array}{lr}
\text { (13) } \begin{array}{lr}
\text { Amaq be-base } & \text { be-tenaq } \\
\text { adek=q=n selapuq } & \text { anak=n } \\
\text { sekolah pacu-pacu. } & \\
\text { father say } & \text { invite } \\
\text { CONJ=3S all child=3S } \\
\text { school diligent }
\end{array} \\
\text { 'Father asks his children to taking } \\
\text { their education seriously.' }
\end{array}
$$

Sasak serial verb constructions share aspect, mood and negation

Aspect marker which is used in Sasak serial is lexical form uah, means 'already done'. Mood which is used in Sasak serial is lexical form eaq, means 'will/ about to'.

(14) Tiang eaq lalo nalet ambon eleq kebon.

1-S MOD go N.plant potato PREP farm

'I will plant some potatoes in the farm.'

Sasak serial verb constructions share the same arguments

Serial verb constructions prototypically share at least one argument. A serial verb construction with no share arguments is rare, but not non-existent (Aikenvald, 2006: 12). Sasak serial verb constructions form a single clause or mono-clause with the same arguments, see the example below:
(15) Kakaq sili Ariq nangis.
sister get.angry listen brother N.cry
'Sister gets angry hearing Brother cries.'

Subject of Sasak Serial Verb
Constructions
SUBJ is a core argument in a clause or
sentence. Linguists use some properties to

prove SUBJ. The example aove shows that SUBJ in Sasak always precedes the verb of clause. Siti is SUBJ of verbs lalo 'go' meli 'buying' from the nasal $m-+$ beli 'to buy.

(16) Siti lalo meli teri. name go N.buy teri 'Siti buys fish'.

Object of Sasak Serial Verb Constructions

Based on the position in constituent structure, $\mathrm{OBJ}$ is always following the verb without any precendence of conjunction. The relation between verb and OBJ is very close.

(17) Amaq dateng nge-beng Inaq kepeng.

father come give mother money

'Father comes to give Mother some money.'

(18) Inaq te-beng kepeng (isiq) Amaq (saq) dateng.

mother PASS-give money Prep father REL come

'Mother has received some money (from) Father who came'

(19) *kepeng te-beng Inaq isiq Amaq (saq) dateng money PASS-give mother Prep father REL come

'Money given Mother by Father who came'

\section{c. The Syntactic Structures of Sasak Serial Verb Constructions}

The concept of serial verb constructions in this context refers to Durie (1988) and Aikhenvald (2006). By using syntactic stuctures, I found that Sasak serial verb constructions form can have $\mathrm{V}-\mathrm{V}$ constructions as single predicate, and can have an X-COM or X-ADJ structure.

Clause (39) below is Sasak serial verb constructions form a single clause or mono-clause with SUBJ Amaq 'Father' as argument sharing. This subject as seen in clause containing a single predicate may be ellipses.

(20) Amaq besoq pandiq montor $=n$. father clean
motorcycle=3S bath
'Father is washing his
motorcycle,' motorcycle.' In LFG, the serial verb construction in
(20) is described by using parallel sentence (20) is described by using paralle
structures, which are c-str and f-str. With the input from the lexical entry as seen in 
(21), and has c-str as seen in (22) and f-str as seen in (23). Note that every node of the c-str is related to some f-str, the annotations have the form of equations such as $\uparrow=\downarrow$, which $\uparrow$ can be read as 'the mother node' and $\downarrow$ as 'ego self'.

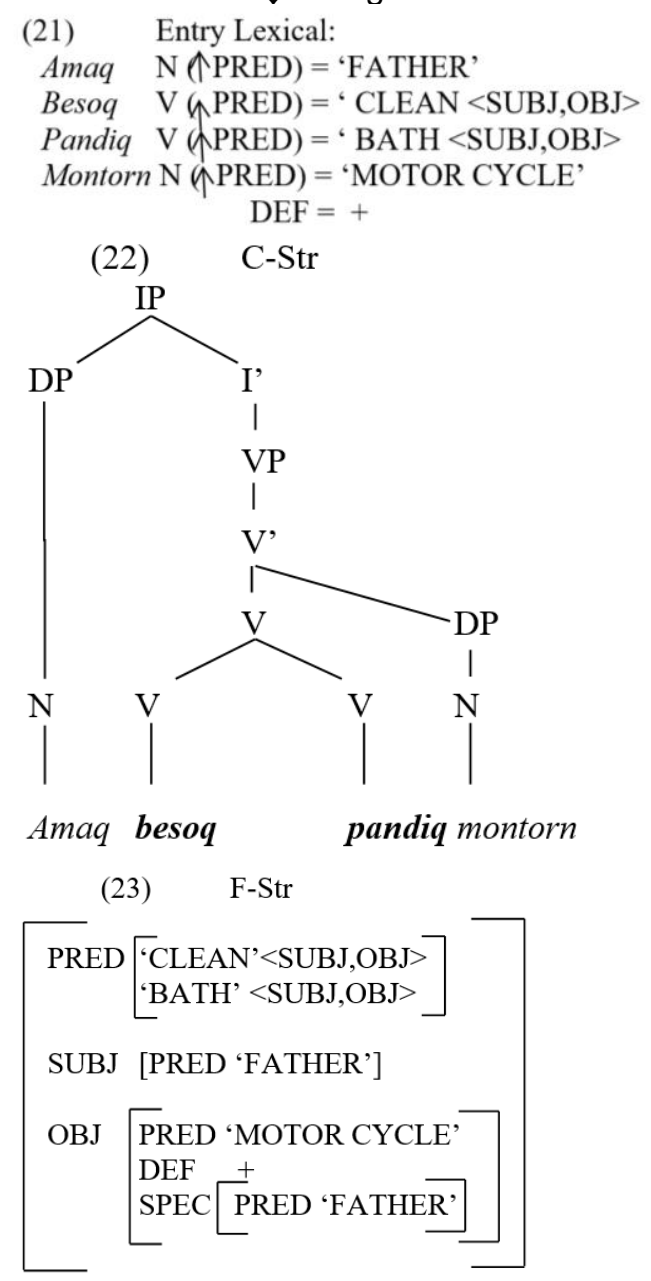

In the c-structure (22), IP (Inflectional Phrase) corresponds to the sentence Amaq besoq pandiq montorn 'Father is washing his motorcycle'. This clause is having V-V construction in besoq 'clean' and pandiq 'wash' means 'washing' treated as a single predicate. The c-structure is parallel with the f-structure. In f-structure (23), we can also see the argument sharing of the verbs. In some cases, Sasak serial verb constructions share objects as well as subjects. When both a subject and an object are presented, they are treated in the same way as they would be in monoverbal clauses.

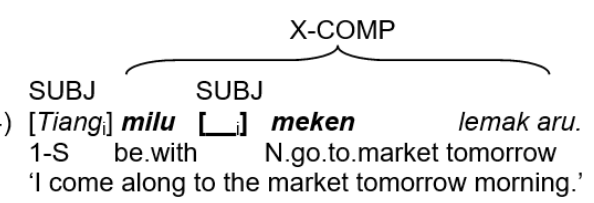

The sentence (24) is comitative serialization. SUBJ of first verb is controller of SUBJ of X-COMP. In this clause, serial verb constructions with $\mathrm{X}$-COMP structure formed by comitative verb milu 'be with/ come along' which followed by other verbs. In LFG, the serial verbs constructions in (24) is described by using parallel structures, which are c-str and f-str. With the input from the lexical entry as seen in (25), it has c-str as shown in (26) and f-str as shown in (27). The followings are the representations:
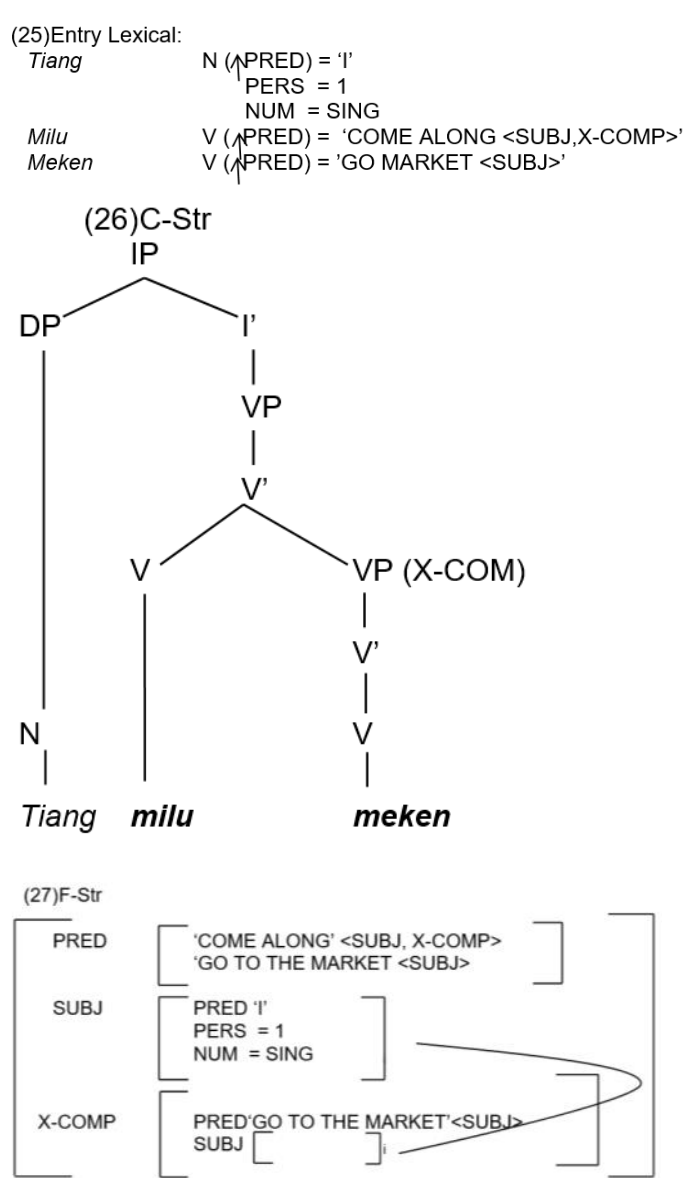

The c-stucture (26) above shows the sentence Tiang milu meken 'I come along to the market' is an IP (Infelctional Phrase). This clause has $V$ milu 'come' as matrix verb and structure of $\mathrm{VP}=(\mathrm{X}-\mathrm{COMP})$ consists of $\mathrm{V}$ meken 'go to market' as subordinate verb. In construction above, V milu 'come' needs X-COMP to complete the clause. The c-structure is parallel with 
the f-structure. In f-stucture (27), we can also see the argument sharing of the verbs, that is, the SUBJ Tiang 'l' of the matrix verb milu 'come along' is the same as the SUBJ of X-COMP.
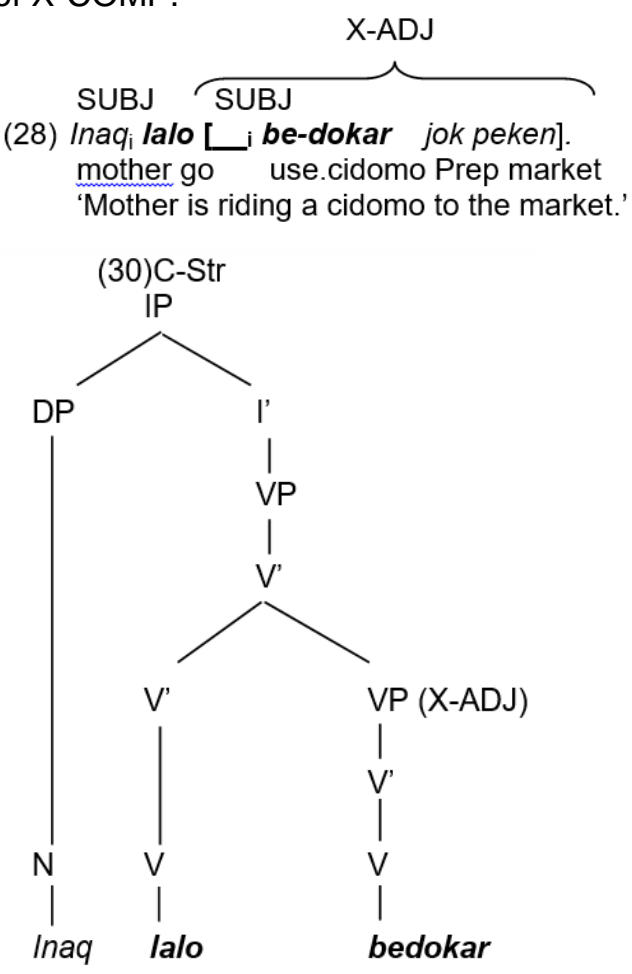

(31)F-Str

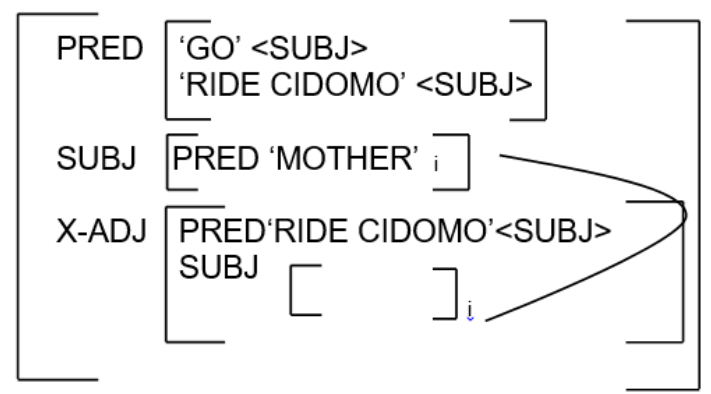

The c-structure (30) above shows the clause 'Inaq lalo bedokar' is an IP (Inflectional Phrase). This clause is instrumental serialization with $\mathrm{VP}=(\mathrm{X}-\mathrm{ADJ})$. In this structure, Inaq 'Mother' as argument SUBJ of matrix verb lalo 'go' is the same as SUBJ of subordinate verb bedokar 'using cidomo'. The existence of second verb is only to clarify the meaning of first verb. However, without second verb, the first verb lalo 'go' is still a complete clause and acceptable. The c-structure is parallel with the f-structure. In f-structure (31), we can also see the argument sharing of the verbs, that is, the SUBJ Inaq 'Mother'.

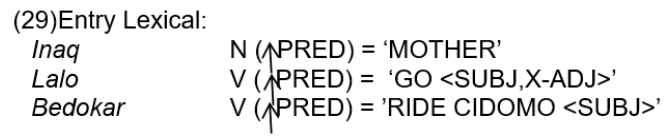

\section{CONCLUSION}

Serial verb constructions in Sasak language can be filled by two verbs or more in independent serialization, or codependent serialization. Typology of serial verb can be determined semantically, phonologically, morphologically, and syntactically. Semantically, Sasak serial verb has ten semantic types, which are motion, direction, instrument, comitative, manner, aspect and mood, benefactive, causative, cause-effect, and synonym.

Based on the phonological, morphological and syntactical characteristics, Sasak serial verb constructions have the following characteristics: (1) Sasak serial verb constructions fall under one intonation contour, 2) Sasak serial verb constructions form mono-clause as a single predicate, 3) Sasak serial verb markers occur only on one verb or each verb obtains the same marker, 4) Sasak serial verb constructions share aspect, mood, and negation, and 5) Sasak serial verb constructions share the same arguments.

Sasak serial verb constuctions have $\mathrm{X}$-COMP structure in aspectual, modal, comitative, motion, and synonym serialization which SUBJ of first verbs is a controller of SUBJ of X-COMP. The forms of X-ADJ structure are found in manner, aspectual, instrumental, motion, directional, cause-effect, and synonym serialization.

\section{REFERENCES}

Aikhenvald, Y. Alexandra. (2006). Serial Verb Construction in Typological Perspective. In Serial Verb Constructions: A Cross-Linguistic Typology. Eds. Alexandra Aikhenvald and R.M.W. Dixon, eds Serial Verb Construction: a crosslinguistic typology, 1-87. London: Oxford University Press.

Austin, Peter K. (2003). The Linguistic Ecology of Lombok. PELBBA 16: 165-198. 
(2011). Tense, aspect, mood and evidentiality in Sasak, eastern Indonesia. Paper given at Chronos 10, Aston University. Retrieved from http://www.hrelp.org/aboutus/staff/pet er_austin/2011_tufs_paper.pdf . (2012). Too many nasal verbs: dialect variation in the voice system of Sasak. Nusa 35:1-18. Retrieved from http://repository.tufs.ac.jp/bitstream/1 0108/71804/2/

Bresnan, Joan. (2001). Lexical Functional Syntax. Oxford: Blackwell Publishers.

Budiarta, I Wayan. (2013). Tipologi Sintaksis Bahasa Kemak. Unpublished doctoral dissertation, Udayana University, Denpasar.

Dalrymple, Mary. (2001). Lexical Functional Grammar: Syntax and Semantics. New York: Academic Press.

Durie, Mark. (1988). Verb Serialization and Verbal Prepositions in Oceanic Languages. Oceanic Linguistics, 27, 1-23.

Liswahyuningsih, Ni Luh Gede. (2011). Indonesian $V-V$ Constructions in "Laskar Pelangi" And Their Translations in "The Rainbow Troops". Unpublished master's thesis, Udayana University, Denpasar.

Pawley, Andrew. (1996). Compact versus narrative serial verb constructions in Kalam. In Gunter Senft (Ed.) Serial Verb Constructions in Austronesian and Papuan Languages. Canberra: Pacific Linguistics RSPAS ANU

Pradnyayanti, Luh Putu Astiti. (2010). Konstruksi Verba Beruntun Bahasa Sasak Dialek Ngeto-Ngete. Unpublished master's thesis, Udayana University, Denpasar.

Subiyanto, Agus. (2013). Predikat Kompleks Bahasa Jawa: Kajian Sintaksis dan Pragmatik. Unpublished doctoral dissertation, Udayana University, Denpasar.

Sudaryanto. 1993. Metode dan Aneka Teknik Analisis Bahasa. Yogyakarta: Duta Wacana University Press.

Sukri, Muhammad. (2008). Sistem Morfologi Bahasa Sasak Dialek KutoKute: Kajian Berdasarkan Morfologi Generatif. Unpublished doctoral dissertation, Udayana University, Denpasar.
Van Staden, Miriam and Ger Reesink. (2008). Serial Verb Constructions in a Linguistic Area. In Gunter Senft (Ed.) Serial Verb Constructions in Austronesian and Papuan Languages. Canberra: Pacific Linguistics RSPAS ANU 